\title{
ANTIOXIDANTS SELENOMETHIONINE AND D-PANTETHINE DIFFERENTIALLY AFFECT DOXORUBICIN'S ACTION ON GLUTATHIONE SYSTEM IN HUMAN LEUKEMIA CELLS VARYING IN THEIR RESISTANCE TO CHEMOTHERAPY IN VITRO
}

\author{
Yu. S. Kozak ${ }^{1,2}$, R. R. Panchuk ${ }^{2 *}$, N. R. Skorokhyd ${ }^{2}$, \\ D. S. Semenovich ${ }^{4}$, A. G. Moiseenok ${ }^{4}$, R. S. Stoika ${ }^{1,2,3}$ \\ ${ }^{1}$ Ivan Franko National University of Lviv, 4, Hrushevskyi St, Lviv 79005, Ukraine \\ e-mail: juliana.kozzak@gmail.com \\ 2 Institute of Cell Biology, NAS of Ukraine, 14-16, Drahomanov St., Lviv 79005, Ukraine \\ ${ }^{3}$ Danylo Halytsky Lviv National Medical University, 69, Pekarska St., Lviv 79010, Ukraine \\ ${ }^{4}$ Institute of Biochemistry of Biologically Active Compounds, NAS of Belarus \\ Boulevard of Leninskiy Komsomol, 50, Grodno 230030, Republic of Belarus \\ ${ }^{*}$ Corresponding author: R. R. Panchuk, e-mail: rpanchuk@ukr.net
}

Kozak Yu. S., Panchuk R. R., Skorokhyd N. R., Semenovich D. S., Moiseenok A. G., Stoika R. S. Antioxidants selenomethionine and D-pantethine differentially affect doxorubicin's action on glutathione system in human leukemia cells varying in their resistance to chemotherapy in vitro. Studia Biologica, 2018: 12(2); 13-24 • https://doi.org/10.30970/sbi.1202.569

Rapid development of multiple drug resistance and occurrence of negative side effects in cancer patients arising at the treatment belong to the main problems in cancer chemotherapy. Recently, it was shown that specific antioxidants (selenomethionine SeMet and D-pantethine - D-Pt) possessed nephro-, myelo- and hepatoprotective activity at doxorubicin's (Dx) action in tumor-bearing mice. Besides, these antioxidants inhibited a cytotoxic action of Dx toward chemotherapy-sensitive tumor cells, and enhanced the cytotoxic effect of this drug toward selected drug-resistant tumor cell lines (e.g. HL-60/vinc, HL-60/adr), while in other such lines (e.g. HCT-116/Bax(-/-), HCT$116 / p 53)$, it was not effective.

The aim of present study was to investigate the molecular mechanisms of the revealed difference in the action of SeMet and D-Pt toward cytotoxic effects of Dx in tumor cells varying in drug resistance. Human leukemia cells of HL-60/wt line and its drugresistant sublines HL-60/adr (overexpression of MRP-1) and HL-60/vinc (overexpression of P-gp) were used in this study.

Treatment of cells with Dx led to the versatile action of this drug on the level of glutathione in each of the studied cell line and sublines. HL-60/wt cells were characterized

(C) 2018 Yu. S. Kozak et al.; Published by the Ivan Franko National University of Lviv on behalf of Біологічні Студії / Studia Biologica. This is an Open Access article distributed under the terms of the Creative Commons Attribution License (http://www.budapestopenaccessinitiative.org/ and Creative Commons Attribution 4.0 License), which permits unrestricted reuse, distribution, and reproduction in any medium, provided the original work is properly cited.

ISSN 1996-4536 (print) • ISSN 2311-0783 (on-line) • Біологічні Студії / Studia Biologica • 2018 • Том 12/№2 • С. 13-24 
by 8-fold lower GSH level under Dx treatment compared to control, while in HL-60/vinc and HL-60/adr cells GSH level was increased 2.2- and 8.2-fold (compared to untreated cells), correspondingly. The use of doxorubicin also led to significant rearrangement of GSSG/GSH ratio in these cell lines, leading to 2-fold elevation of GSSG level HL-60/vinc cells, and 2.5-fold decrease of this index in HL-60/adr cells.

We have shown that a combined effect of SeMet or D-Pt on the background of the cytotoxic action of doxorubicin on HL-60/vinc cells is accompanied by a 2-fold decrease in both oxidized and reduced glutathione levels. Such an effect of these antioxidants can serve as an explanation of their sensitizing effect on the cells of the HL-60/vinc subline under Dx's action which we observed earlier. It should be noted that treatment with Dx led to a 2.5-fold increase in the activity of glutathione-S-transferase in the leukemia cells of HL-60/vinc subline. The antioxidants effectively reduced this indicator. SeMet and D-Pt differentialy affected the activity of glutathione-S-transferase in HL-60/adr cells.

In conclusion, our data demonstrate an important role of the antioxidants on the functional state of the glutathione system in tumor cells that differ in their drug resistance. The obtained results suggest an important role of glutathione-S-transferase in modulation of cancer drug resistance that is caused by $\mathrm{P}$-glycoprotein overexpression, but not by the overexpression of MRP-1 protein. Selenomethionine and D-pantethine effectively inhibit this enzyme, thus, sensitizing P-gp overexpressing cells towards the action of doxorubicin. This event is accompanied by further decrease in GSH and GSSG levels in these cells, thus sensitizing them to Dx action. Further studies of the molecular mechanisms underlying this phenomenon are in progress.

Keywords: doxorubicin, antioxidants, glutathione, glutathione peroxidase, glutathione reductase, glutathione-S-transferase

\section{INTRODUCTION}

Chemotherapy is the main treatment method of cancer today. But traditional anticancer drugs don't always provide a complete remission. Besides a lot of antitumor drugs have some side effects, because they affect both malignant and normal cells of organism. In addition, one of the main problem of modern chemotherapy is rapid development of the multidrug resistance (MDR) of malignant cells. It significantly reduces the effectiveness of treatment of the oncological patients. This phenomenon is associated with an elevated expression of membrane-bound ATP binding cassette transporter proteins (ABC transporters) that pump out the anticancer drugs from the malignant cells [6]. The ABC-transporters play an important role in human organism, protecting healthy tissues (in particular, liver, small and large intestines and kidney) from the action of various xenobiotics [1]. However, their overexpression in the malignant cells significantly reduces the sensitivity of tumors to chemotherapy. P-gp (P-glycoprotein), MRP-1 (multidrug-resistance associated protein) and BCRP (breast cancer resistance protein) are the most important members of this family, and, thus, development of novel efficient inhibitors of these proteins remains an actual task in modern oncology $[4,5,13]$.

The solution of the main problems of chemotherapy is possible using specific agents which reduce the negative side effects of antitumor drugs and by which the phenomenon of multiple drug resistance could be overcome. In previous studies, we have shown that antioxidants selenomethionine (SeMet) and D-pantethine (D-Pt) are promising candidates for the role of such agents. It was found that antioxidant supplements possess

ISSN 1996-4536 (print) • ISSN 2311-0783 (on-line) • Біологічні Студії / Studia Biologica • 2018 • Том 12/№2 • C. 13-24 
nephro-, myelo- and hepatoprotective activity toward doxorubicin (Dx) action on the organism of tumor-bearing mice. Also, these antioxidants partially sensitized drugresistant tumor cells toward cytotoxic action of the doxorubicin (Dx) [15-17]. However, the molecular mechanisms underlying such effects of selenomethionine and D-pantethine remain unexplored.

One of the mechanism for the emergence of multiple drug resistance is the glutathione system. It is known that the antioxidants are potential modulators of cellular glutathione system that is often involved in regulation of drug resistance in tumor cells $[23,24]$. Glutathione is a biologically active tripeptide. Sulfhydryl group of this thiol (R-SH) interacts with the reactive group of the chemotherapeutic drug to form a conjugate. Such conjugates are less active and are removed from the cell by ATP binding cassette transporter proteins. Chemical interactions between glutathione and antitumor compounds are catalyzed by glutathione-S-transferase enzymes. Glutathione-S-transferases (GSTs) are a family of detoxification enzymes that catalyse the conjugation of glutathione (GSH) to a wide variety of endogenous and exogenous compounds.

Literature data confirm an important role of reduced glutathione (GSH) and glutathione-S-transferase in transport and accumulation of anticancer drugs in drug-resistant tumor cells. Thus, it was demonstrated that that elevated levels of GSH, together with increased activities of glutathione-S-transferase (GST) or peroxidase, may protect cells from cytotoxic drugs (platinum compounds and anthracyclines). Conversely, depletion of the cellular glutathione (GSH) levels inhibits the transport of the drug through inhibition of the transport of glutathione S-conjugates [22, 24]. It is known that cytosolic GSTs of some classes play a regulatory role in the mitogen-activated protein (MAP) kinase pathway that participates in cellular survival and death signals. So GSTs perform their function by direct detoxification or act as inhibitors of the MAP kinase pathway. Such an effect of GSTs on the MAP kinase pathway explains why in many cases the drugs used to select for resistance don't conjugate with GSH and are not substrates for GSTs [22, 23].

So, the aim of this study was to address potential mechanisms of the effect of antioxidant compounds on the functional state of the glutathione system in tumor cells that differ in their drug resistance.

\section{MATERIALS AND METHODS}

Human leukemia HL-60 cell line and its drug-resistant sublines HL-60/adr (overexpression of MRP-1) and HL-60/vinc (overexpression of P-glycoprotein) were kindly provided by prof. Walter Berger (cell culture collection at the Institute of Cancer Research, Vienna Medical University, Austria).

Cells were cultured in the RPMI-1640 medium (Sigma-Aldrich, St. Louis, USA) supplemented with $10 \%$ fetal calf serum (Sigma-Aldrich, St. Louis, USA), $50 \mu \mathrm{g} / \mathrm{ml}$ streptomycin (Sigma-Aldrich, St. Louis, USA), and 50 units/ml penicillin (Sigma-Aldrich, St. Louis, USA) in $5 \% \mathrm{CO}_{2}$ humidified atmosphere at $37^{\circ} \mathrm{C}$. During experiments, cells $\left(1 \times 10^{6}\right.$ per $\left.\mathrm{ml}\right)$ were incubated for $24 \mathrm{~h}$ in 6 -well tissue culture plates (Greiner Bio-one, Frickenhausen, Germany), and the substances was added at various concentrations (doxorubicin in a dose of $1 \mu \mathrm{M}$ for HL-60/wt cells, $5 \mu \mathrm{M}$ for HL-60/vinc cells and $10 \mu \mathrm{M}$ for HL-60/adr cells). The concentration of the antioxidants was the same for all studied cell lines, namely $0.2 \mu \mathrm{M}$ for selenomethionine and $10 \mu \mathrm{M}$ for D-pantethine. Cytotoxic effects of Dx and antioxidants were evaluated under Evolution 300 Trino microscope

ISSN 1996-4536 (print) • ISSN 2311-0783 (on-line) • Біологічні Студії / Studia Biologica • 2018 • Том 12/№2 • C. 13-24 
(Delta Optical, Nowe Osiny, Poland) by staining the dead cells with trypan blue dye $(0.1 \%)$. After that, cells were centrifuged at $1,500 \mathrm{rpm}$ for $5 \mathrm{~min}$, and cell suspension was washed twice with a phosphate buffered saline.

The measurement of glutathione was carried out using the Ellman's Reagent (DTNB - 5,5'-Dithiobis-2-Nitrobenzoic Acid), which forms a colored complex with a maximal absorption at $412 \mathrm{~nm}$ with $\mathrm{SH}$-groups at $\mathrm{pH} 8.0$ and with SS-groups at $\mathrm{pH} 10.5$. Cell suspension was deproteinized with $0.4 \mathrm{ml}$ of $50 \%$ sulfosalicylic acid, centrifuged, and the resulting supernatant was neutralized to $\mathrm{pH} 7.6$ by the addition of $0.1 \mathrm{ml}$ of cooled $2.5 \mathrm{M} \mathrm{K}_{3} \mathrm{PO}_{4}$. After additional centrifugation, the entire supernatant was mixed with $2 \mathrm{ml}$ of phosphate buffer ( $\mathrm{pH} 8.0$ ) containing $0.004 \%$ Ellman's reagent. The optical density of the solution was measured by a spectrophotometer SF-46 (LOMO, Russian Federation) at a wavelength of $412 \mathrm{~nm}$. After that, $\mathrm{pH}$ in the cuvette was quickly increased to 10.5 , and a marked increase in absorption was observed. The content of the oxidized glutathione (GSSG) was calculated as the difference between absorption of complex of Ellman's reagent at $\mathrm{pH} 10.5$ and $\mathrm{pH} 8.0$ [19].

The glutathione reductase (GR, EC 1.8.1.7) activity was determined as the oxidation rate of NADPH by the oxidized glutathione (GSSG)n that was recorded spectrophotometrically. $100 \mu \mathrm{l}$ of supernatant was added to $2.4 \mathrm{ml}$ of $0.01 \mathrm{M}$ phosphate buffer $(\mathrm{pH}$ 7.4) containing $1 \mathrm{mM}$ EDTA, $2 \mathrm{mM}$ GSSG and $0.2 \mathrm{mM} \mathrm{NADPH}$, and the absorption decrease was recorded at $340 \mathrm{~nm}$ [3]. The glutathione transferase (GST, EC 2.5.1.18) activity was determined as the rate of formation of a conjugate between reduced glutathione (GSH) and CDNB (1-Chloro-2,4-dinitrobenzene). $50 \mu$ of samples were added to $2 \mathrm{ml}$ of $0.1 \mathrm{M}$ phosphate buffer ( $\mathrm{pH} \mathrm{6.5)} \mathrm{containing} 2.5 \mathrm{mM}$ of $\mathrm{GSH}$ and $1.0 \mathrm{mM}$ of CDNB. Then the absorption increase at $340 \mathrm{~nm}$ was recorded using a molar absorption coefficient $\left(9.6 \mathrm{~mm}-1 \mathrm{~cm}^{-1}\right)$ [18]. The glutathione peroxidase (GPx, EC 1.11.1.9) activity was measured by the colorimetric method using a decrease of GSH concentration under reaction with several types of hydroperoxides. For determination of the GPx activity of the method of V. M. Moin [11]. A solution of tert-butyl hydroperoxide (20 mM) was added to the reaction mixture containing $100 \mu$ l cell suspension (1:29), $830 \mu \mathrm{l}$ Tris buffer $(0.1 \mathrm{M}, \mathrm{pH} 8.5$ with addition of $6 \mathrm{mmol}$ EDTA, $9.96 \mu \mathrm{mol}$ sodium azide and $4.8 \mathrm{mmol}$ GSH). The amount of GSH consumed in the process of interaction between the enzyme and the substrate was determined spectrophotometrically at $412 \mathrm{~nm}$ upon the appearance of a colored thionitrofenyl product of 5,5'-dithiobis-2-nitrobenzoic acid, taking into account the molar extinction coefficient (13 100) of the Ellman's reagent.

All experiments were performed in triplicate and repeated 3 times. Statistical analysis of data was conducted in GraphPad Prism Software (GraphPad Software, Inc) using Student's t-test. Statistical significance was set at $P \leq 0.05$.

\section{RESULTS AND DISCUSSION}

In order to reveal potential interrelations between glutathione level and sensitivity of tumor cells to anticancer drugs, cellular content of oxidized (GSSG) and reduced glutathione (GSH) was studied in human leukemia HL-60/wt cell line and its drug-resistant sublines. It was found that basal GSH level was identical both in HL-60/wt cells and its vincristine-resistant HL-60/vinc subline (overexpressing P-glycoprotein), while in doxorubicin-resistant cells of HL-60/adr subline (overexpression of MRP-1) this index was 2-fold lower (Fig.1, Table 1). On contrary, basal level of oxidized glutathione (GSSG) was increased 2-fold in HL-60/adr subline, while HL-60/vinc cells were characterized by

ISSN 1996-4536 (print) • ISSN 2311-0783 (on-line) • Біологічні Студії / Studia Biologica • 2018 • Том 12/№2 • C. 13-24 
6-fold lower level of GSSG compared to the parental cells. So, the cells of each of the studied cell lines are characterized by different basal levels of both oxidized and reduced glutathione, leading to different GSH/GSSG ratios - 0.34 in HL-60/wt, 2.2 in HL60/vinc and 0.06 in HL-60/adr (Fig.1, Table 1). Such a difference in these indices may be explained by overexpression of $A B C$-transporter proteins in drug-resistant tumor cells, which can utilize glutathione for ther own needs. In particular, it is known that overexpression of MRP-1 protein is closely related to an increased level of glutathione in tumor cells [24]. GSH forms adducts with anticancer drugs which are then pumped out from cells by the MRP-1 protein. At the same time, the expression of P-glycoprotein is not directly related to the level of cellular glutathione [24] that might explain another pattern of its level in the cells of the HL-60/vinc subline.
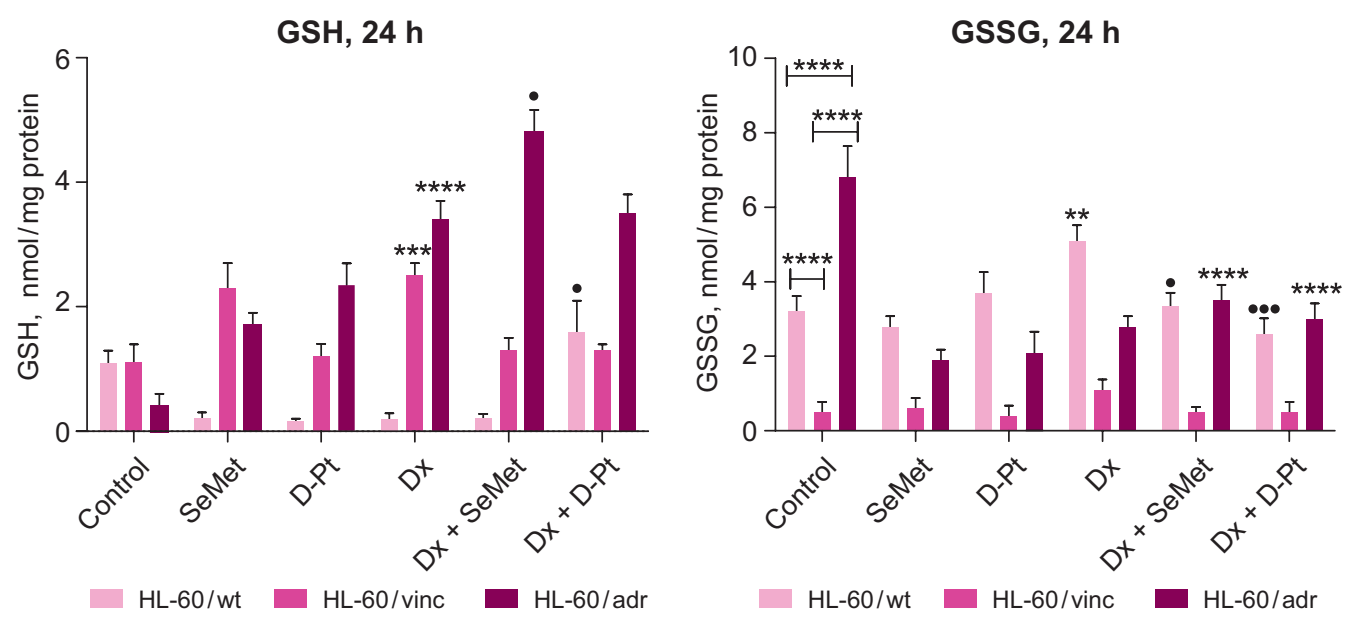

Fig. 1. Impact of selenomethionine (SeMet) and D-pantethine(D-Pt) on the level of reduced(GSH) and oxidized glutathione (GSSG) in human leukemia cells of the HL-60/wt line and its resistant subline HL60/adr and HL-60 /vinc under doxorubicin (Dx) action (24 h incubation). * $-\mathrm{P}<0.05$; ${ }^{* *}-\mathrm{P}<0.01$; ${ }^{* * *}-\mathrm{P}<0.001 ;{ }^{* * * *}-\mathrm{P}<0.0001$ (vs control); •- $\mathrm{P}<0.05 ; \cdots-\mathrm{P}<0.001$ (vs doxorubicin)

Рис. 1. Вплив селенометіоніну (SeMet) і D-пантетину (D-Pt) на рівень відновленого (GSH) і окисленого глутатіону (GSSG) у клітинах лейкозу людини лінії HL-60/wt і її резистентних субліній HL-60/adr та HL-60/vinc під час дії на них доксорубіцину(Dx) (24 год інкубації). * - P <0,05; ** - P <0,01; *** $\mathrm{P}<0,001 ;{ }^{* * * *}-\mathrm{P}<0,0001$ (порівняно $з$ контролем); •- $\mathrm{P}<0,05 ; \cdot \cdots-\mathrm{P}<0,001$ (порівняно $з$ доксорубіцином)

The next aim of this work was to study if specific modulators of cellular glutathione system (selenomethionine, SeMet and D-pantethine, D-Pt) might sensitize drug-resistant tumor cells to the action of various anticancer drugs. It is known that selenium is a coenzyme of glutathione peroxidase and plays an important role in the regulation of the glutathione system [20]. D-pantethine is the precursor of coenzyme A, which is involved in most metabolic processes in the cell $[2,12]$. Both compounds led to major reduction of GSH levels in HL-60/wt cells, insignificantly influenced on this index in HL60/vinc cells and massively (3- and 6-fold, correspondingly) enhanced it in HL-60/adr cells. On contrary, there was no impact of SeMet and D-Pt on GSSG levels in HL-60/wt and HL-60/vinc cells, but in HL-60/adr cells it was significantly (2- and 2.4-fold, correspondingly) decreased (Fig.1, Table 1). These data clearly indicate on activation of 
MRP-1 protein in HL-60/adr cells under their treatment with SeMet and D-Pt, that is accompanied by significant rearrangement in cellular GSH/GSSG ratio.

In order to confirm this suggestion, we studied changes in cellular GSH and GSSG levels under impact of well-known anticancer drug doxorubicin (Dx) that is a typical classic substrate of ABC-transporter proteins [21]. Treatment of cells with Dx led to the versatile action of this drug on the level of glutathione in each of the studied cell line and sublines. HL-60/wt cells were characterized by 8-fold lower GSH level under Dx treatment compared to control, while in HL-60/vinc and HL-60/adr cells GSH level was increased 2.2- and 8.2-fold (compared to the untreated cells), correspondingly (Fig. 1, Table 1). These results clearly indicate an activation of ABC-transporter proteins in MDR cell lines under Dx treatment that requires reduced glutathione for their activity. This event also led to a significant rearrangement of GSSG/GSH ratio in these cell lines, leading to 2-fold elevation of GSSG

Table 1. Impact of selenomethionine (SeMet) and D-pantethine (D-Pt) on the level of glutathione (reduced - GSH and oxidized - GSSG) and on the activity of glutathioneS-transferase (GST) in human leukemia cells of the HL-60/wt line and its resistant subline HL-60/adr and HL-60/vinc under doxorubicin (Dx) action

Таблиця 1. Вплив селенометіоніну (SeMet) i D-пантетину (D-Pt) на рівень глутатіону (відновленого - GSH і окисленого - GSSG) і активність глутатіон-S-трансферази (GST) у клітинах лейкемії людини лінії HL-60/wt та її резистентних субліній HL-60/adr i HL-60/vinc під дією доксорубіцину (Dx)

\begin{tabular}{|c|c|c|c|c|c|c|c|c|c|}
\hline & \multicolumn{3}{|c|}{ HL-60/wt } & \multicolumn{3}{|c|}{ HL-60/vinc } & \multicolumn{3}{|c|}{ HL-60/adr } \\
\hline & GSSG & GSH & GST & GSSG & GSH & GST & GSSG & GSH & GST \\
\hline $\begin{array}{l}\text { No } \\
\text { treatment }\end{array}$ & basal & basal & basal & $\downarrow 6 x$ & no effect & $\uparrow 2 x$ & $\uparrow 2.1 \mathrm{x}$ & $\downarrow 2.7 x$ & $\uparrow 2 x$ \\
\hline $\mathrm{D}-\mathrm{Pt}$ & no effect & $\downarrow 7 x$ & no effect & $\begin{array}{c}\downarrow 8 x \\
\text { (no effect) } \#\end{array}$ & no effect & $\begin{array}{c}\uparrow 2.1 x \\
\text { (no effect) }\end{array}$ & $\begin{array}{c}\downarrow 1.5 x \\
(\downarrow 3.2 x)^{\wedge}\end{array}$ & $\begin{array}{c}\uparrow 2.1 x \\
(\uparrow 5.8 x)^{\wedge}\end{array}$ & $\begin{array}{c}\uparrow 1.9 x \\
\text { (no effect) }\end{array}$ \\
\hline SeMet & no effect & $\downarrow 5.5 x$ & $\downarrow 1.7 x$ & $\begin{array}{c}\downarrow 5.3 x \\
\text { (no effect) } \#\end{array}$ & $\begin{array}{c}\uparrow 2 x \\
(\uparrow 2 x)^{\#}\end{array}$ & $\begin{array}{c}\uparrow 3.1 x \\
(\uparrow 1.5 x)^{\#}\end{array}$ & $\begin{array}{c}\downarrow 1.6 x \\
(\downarrow 3.5 x)^{\wedge}\end{array}$ & $\begin{array}{c}\uparrow 1.5 x \\
(\uparrow 4.2 x)^{\mathbf{4}}\end{array}$ & $\begin{array}{c}\downarrow 3.5 x \\
(\downarrow 6.8 x)^{\mathbf{4}}\end{array}$ \\
\hline Dx & $\uparrow 1.5 x$ & $\downarrow 7.3 x$ & $\uparrow 1.4 \mathrm{x}$ & $\begin{array}{l}\downarrow 2.9 x \\
(\uparrow 2 x)^{\#}\end{array}$ & $\begin{array}{c}\uparrow 2.2 x \\
(\uparrow 2.2 x)^{\#}\end{array}$ & $\begin{array}{c}\uparrow 4.4 x \\
(\uparrow 2.1 x)^{\#}\end{array}$ & $\begin{array}{l}\text { no effect } \\
(\downarrow 2.4 x)^{\wedge}\end{array}$ & $\begin{array}{c}\uparrow 3 x \\
(\uparrow 8.2 x)^{\wedge}\end{array}$ & $\begin{array}{c}\uparrow 1.9 x \\
\text { (no effect) }\end{array}$ \\
\hline$D x+D-P t$ & $\begin{array}{c}\text { no effect } \\
(\downarrow 1.9 x)^{\mathbf{*}}\end{array}$ & $\begin{array}{l}\uparrow 1.4 x \\
(\uparrow 8 x)^{\prime}\end{array}$ & $\begin{array}{c}\uparrow 1.1 \mathrm{x} \\
\text { (no effect)" }\end{array}$ & $\begin{array}{l}\downarrow 6.4 x \\
(\downarrow 2 x)^{\vee}\end{array}$ & $\begin{array}{l}\text { no effect } \\
(\downarrow 1.9 x)^{\nabla}\end{array}$ & $\begin{array}{c}\uparrow 1.8 x \\
(\downarrow 2.4 x)^{\vee}\end{array}$ & $\begin{array}{c}\text { no effect } \\
\text { (no effect) }\end{array}$ & $\begin{array}{c}\uparrow 3.1 \mathrm{x} \\
\text { (no effect) }\end{array}$ & $\begin{array}{c}\uparrow 1.7 x \\
\text { (no effect) }\end{array}$ \\
\hline $\begin{array}{l}\text { Dx + } \\
\text { SeMet }\end{array}$ & $\begin{array}{c}\text { no effect } \\
(\downarrow 1.5 x)\end{array}$ & $\begin{array}{c}\downarrow 5.5 x \\
\text { (no effect) }\end{array}$ & $\begin{array}{c}\uparrow 1.3 x \\
\text { (no effect)" }\end{array}$ & $\begin{array}{l}\downarrow 6.4 x \\
(\downarrow 2 x)^{\vee}\end{array}$ & $\begin{array}{c}\text { no effect } \\
(\downarrow 1.9 x)^{\nabla}\end{array}$ & $\begin{array}{c}\uparrow 2.2 x \\
(\downarrow 1.9 x)^{\nabla}\end{array}$ & $\begin{array}{c}\text { no effect } \\
\text { (no effect) }\end{array}$ & $\begin{array}{c}\uparrow 4.3 x \\
(\uparrow 1.4 x)^{\bullet}\end{array}$ & $\begin{array}{c}\uparrow 4 x \\
(\uparrow 1.5 x)^{\bullet}\end{array}$ \\
\hline
\end{tabular}

Comments: \# - compared to HL-60/vinc, control; $\boldsymbol{\nabla}$ - compared to HL-60/vinc, Dx; $\boldsymbol{\Delta}$ - compared to HL-60/adr, control; •- compared to HL-60/adr, Dx; - - compared to HL-60/wt, Dx

Примітки: \# - порівняно з клітинами сублінії HL-60/vinc, контроль; $\boldsymbol{\nabla}$ - порівняно з клітинами сублінії HL-60/vinc, Dx; $\boldsymbol{\Delta}$ - порівняно з клітинами сублінії HL-60/adr, контроль; • - порівняно з клітинами сублінії HL-60/adr, Dx; - - порівняно з клітинами лінії HL-60/wt, Dx

ISSN 1996-4536 (print) • ISSN 2311-0783 (on-line) • Біологічні Студії / Studia Biologica • 2018 • Том 12/№2 • С. 13-24 
level HL-60/vinc cells, and 2.5-fold decrease of this index in HL-60/adr cells. Concluding, enhancement of cellular GSH level and loss of GSSG level under Dx treatment indicates on increased tumor cell resistance to this drug, while a decrease in GSH level, accompanied with an increase of GSSG level demonstrates the opposite situation.

We have shown that a combined effect of SeMet or D-Pt on the background of the cytotoxic action of doxorubicin on HL-60/vinc cells is accompanied by a 2-fold decrease in both oxidized and reduced glutathione levels (Fig. 1, Table 1). Such an effect of these antioxidants can serve as an explanation of their sensitizing effect on the cells of the HL-60/vinc subline under Dx's action, which we observed earlier [15].

For revealing the molecular mechanisms underlying this phenomenon, the impact of doxorubicin, SeMet and D-Pt on the activity of key enzymes (glutathione peroxidase (GPx), glutathione reductase (GR) and glutathione-S-transferase (GST) of the glutathione system was studied. We did not detect significant changes in the activity of glutathione peroxidase in the studied cell line and sublines. There was no effect of the antioxidants and Dx on these indicators as well (Fig. 2).

GPx, 24 h

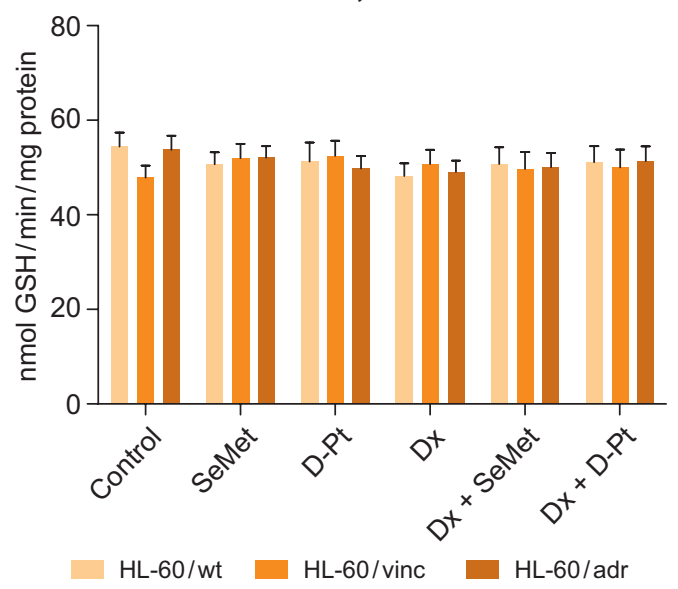

GP, 24 h

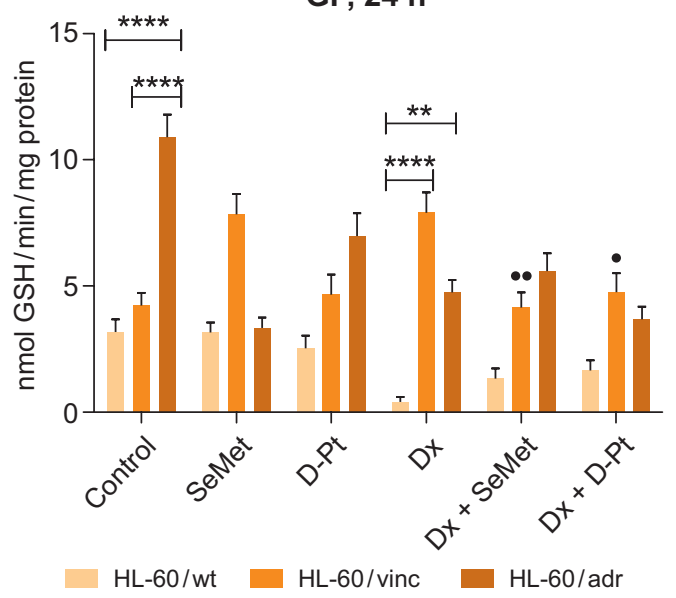

Fig. 2. Impact of joint application of selenomethionine (SeMet) or D-pantethine (D-Pt) with doxorubicin (Dx) on the activity of glutathione peroxidase (GPx) and glutathione reductase (GR) in human leukemia cells of the HL-60/wt line and its resistant subline HL-60/adr and HL-60/vinc (24 $\mathrm{h}$ incubation). ). ${ }^{*}$ $\mathrm{P}<0.01$; ${ }^{* * *}-\mathrm{P}<0.0001$ (vs control); $\bullet-\mathrm{P}<0.05 ; \cdot \bullet-\mathrm{P}<0.01$ (vs doxorubicin)

Pис. 2. Комбінований вплив селенометіоніну (SeMet) або D-пантетину (D-Pt) з доксорубіцином (Dx) на активність глутатіонпероксидази (GPx) і глутатіонредуктази (GR) у клітинах лейкозу людини лінії HL-60/wt і її резистентних субліній HL-60/adr i HL-60/vinc (24 год інкубації). ${ }^{* *}-\mathrm{P}<0,01$; *** $\mathrm{P}<0,0001$ (порівняно з контролем); • - P $<0,05 ; \cdot \bullet-\mathrm{P}<0,01$ (порівняно $з$ доксорубіцином)

The glutathione reductase activity was considerably (10 times) reduced under the action of Dx on wild-type leukemia cells (HL-60/wt), and it was partially recovered under the action of this drug in a combination with SeMet or D-Pt (Fig. 2). Thus, we found a positive correlation between the activity of this enzyme and the level of reduced glutathione under the influence of Dx that is consistent with the literature data [7]. At the same time, the cells of HL-60/vinc and HL-60/adr sublines showed a completely different activity of this enzyme (Fig. 2). In particular, the overexpression of the MRP-1 protein in HL-60/adr cells was accompanied by a 3-fold increase in the activity of glutathione

ISSN 1996-4536 (print) • ISSN 2311-0783 (on-line) • Біологічні Студії / Studia Biologica • 2018 • Том 12/№2 • C. 13-24 
reductase. This activity was lowered twice under the action Dx, while both antioxidants did not demonstrate a modulating effect here. Basal activity of glutathione reductase in $\mathrm{HL}-60 / v i n c$ cells did not differ from this level in the wild-type cells (HL-60/wt), while Dx treatment led to a 2-fold increase in the activity of this enzyme. SeMet and D-Pt partially normalized the level of that indicator (Fig. 2).

Most significant changes were detected at analysis of the activity of glutathione-Stransferase in tumor cells (Fig. 3, Table 1). In both drug-resistant sublines of the leukemia cells, there was a 2-fold increase of the activity of this enzyme. These results are consistent with the literature data about the glutathionylation of xenobiotics and drugs as an important step before their excretion from cells by the ABC-transporters [8, 10, 23]. Treatment of HL-60/vinc cells with Dx led to a 2.5-fold increase of glutathione-Stransferase activity, which also positively correlated with 2-fold increase of GSH level in these cells. Both SeMet or D-Pt lowered GST activity to a basal level, thus, leading to subsequent decrease in GSH and GSSG levels (Fig. 3, Table 1). These data indicate a pronounced inhibitory effect of both antioxidants on the activity of glutathione-S-transferase that might be explained by their ability to enhance the action of the doxorubicin on the malignant cells resistant to chemotherapy (showed by us in [15]).

GST, 24 h

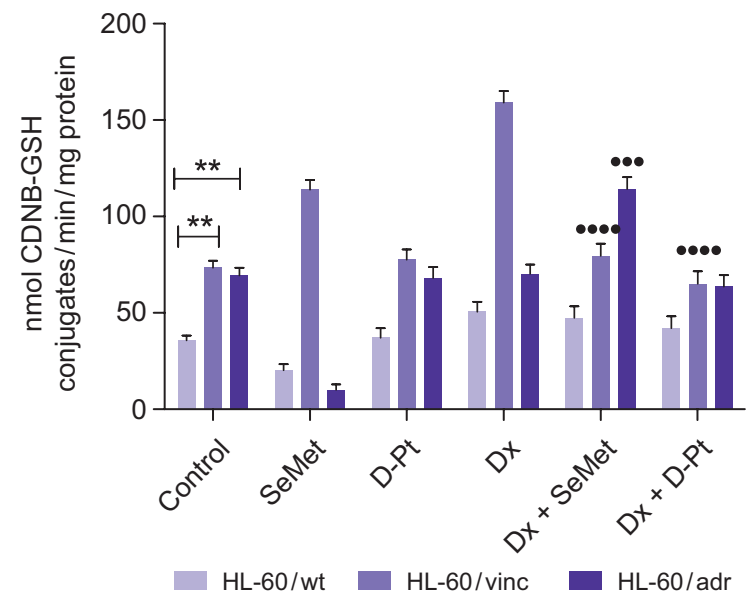

Fig. 3. Impact of selenomethionine and D-pantethine on the activity of glutathione-S-transferase (GST) in human leukemia cells of the HL-60/wt line and its resistant subline HL-60/adr (MRP-1 +) and HL-60/ vinc $(\mathrm{P}-\mathrm{gp}+)$ under the action of doxorubicin $\left(24 \mathrm{~h}\right.$ incubation). ${ }^{* \star}-\mathrm{P}<0.01$ (vs control); $\cdots \mathrm{P}<0.001$; ...- P <0.0001 (vs doxorubicin).

Рис. 3. Вплив селенометіоніну (SeMet) і D-пантетину (D-Pt) на активність глутатіон-S-трансфрерази (GST) у клітинах лейкозу людини лінії HL-60/wt і її резистентних субліній HL-60/adr (MRP-1 +) та HL-60/vinc (P-gp +), які піддавалися обробці доксорубіцином (Dx) (24 год інкубації). ). ${ }^{* *}-\mathrm{P}<0,01$ (порівняно з контролем); $\cdots-$ P $<0,001 ; \cdots-$ - $<<0,0001$ (порівняно з доксорубіцином)

It should be stressed that similar effect of SeMet and D-Pt on the activity of glutathione-S-transferase in drug-resistant HL-60/adr cells was absent, probably due to another mechanism of drug resistance in these cells. Moreover, a co-treatment of HL-60/adr cells with SeMet and Dx led to an enhancement of GST activity, accompanied by increase of GSH levels in these cells (Fig.1, Fig. 3). Thus, SeMet and D-Pt can sensitize to chemotherapy only the P-gp-overexpressing tumor cells, and had a weak influence on MRP-1 overexpressing cancer cell lines.

ISSN 1996-4536 (print) • ISSN 2311-0783 (on-line) • Біологічні Студії / Studia Biologica • 2018 • Том 12/№2 • С. 13-24 


\section{CONCLUSIONS}

The obtained results suggest an important role of glutathione-S-transferase in modulation of cancer drug resistance that is caused by $\mathrm{P}$-glycoprotein overexpression, but not by the overexpression of MRP-1 protein. Selenomethionine and D-pantethine effectively inhibit this enzyme, thus, sensitizing P-gp overexpressing cells towards the action of doxorubicin. This event is accompanied by further decrease in GSH and GSSG levels in these cells, thus sensitizing them to Dx action. Further studies of the molecular mechanisms underlying this phenomenon are in progress.

\section{ACKNOWLEDGMENTS}

This work was supported by a joint Ukraine-Belarus grant financed by the State Fund of Fundamental Research of Ukraine (\#F73/105-2016) and the State Fund of Fundamental Research of Belarus. The authors are also grateful to the staff of the Department of Vitaminology and Nutraceutics at the Institute of Biochemistry of Biologically Active Compounds in Grodno (Belarus) for their assistance in carrying out the experiments.

1. Beis K. Structural basis for the mechanism of ABC transporters. Biochem. Soc. Trans, 2015; 43(5): 889-893.

[DOI: https://doi.org/10.1042/BST20150047; PMID: 26517899; Google Scholar]

2. Branca D, Scutari $G$, Siliprandi N. Pantethine and pantothenate effect on the CoA content of rat liver. International journal for vitamin and nutrition research, 1983; 54(2-3): 211-216. [PMID: 6500846; Google Scholar]

3. Carlberg I., Mannervik B. Glutathione reductase. Methods Enzymol, 1985; 113: 484-90. [DOI:https://doi.org/10.1016/S0076-6879(85)13062-4; PMID: 3003504; Google Scholar]

4. Choi Y.H., Yu A.M. ABC transporters in multidrug resistance and pharmacokinetics, and strategies for drug development. Curr. Pharm, 2014; 20(5): 793-807.

[PMID: 23688078; Google Scholar]

5. Eberl S., Renner B., Neubert A., Reisig M., Bachmakov .I, König J., Dörje F., Mürdter T.E., Ackermann A., Dormann H., Gassmann K.G., Hahn E.G., Zierhut S., Brune K., Fromm M.F. Role of P-glycoprotein inhibition for drug interactions: evidence from in vitro and pharmacoepidemiological studies. Clin. Pharmacokinet, 2007; 46(12): 1039-1049.

[DOI: https://doi.org/10.2165/00003088-200746120-00004; PMID: 18027988; Google Scholar]

6. Gottesman M.M., Fojo T., Bates S.E. Multidrug resistance in cancer: role of ATP-dependent transporters. Nat. Rev. Cancer, 2002; 2(1): 48-58.

[DOI: https://doi.org/10.1038/nrc706; PMID: 11902585; Google Scholar]

7. Gustafson D.L., Swanson J.D., Pritsos C.A. Modulation of glutathione and glutathione dependent antioxidant enzymes in mouse heart following doxorubicin therapy. Free Radic Res Commun, 1993; 19(2): 111-120.

[DOI: https://doi.org/10.3109/10715769309056505; PMID: 8225037; Google Scholar]

8. Hayes J.D., Pulford D.J. The glutathione S-transferase supergene family: regulation of GST and the contribution of the isoenzymes to cancer chemoprotection and drug resistance. Crit. Rev. Biochem. Mol. Biol,1995; 30(6): 445-600.

[DOI: https://doi.org/10.3109/10409239509083491; PMID: 8770536; Google Scholar]

9. Iwamoto $T$. Clinical application of drug delivery systems in cancer chemotherapy: review of the efficacy and side effects of approved drugs. Biol. Pharm. Bull, 2013; 36(5): 715-718. [DOI: https://doi.org/10.1248/bpb.b12-01102; PMID: 23649331; Google Scholar] 
10. Mohn C., Häcker H.G., Hilger R.A., Gütschow M., Jaehde U. Defining the role of MRP-mediated efflux and glutathione in detoxification of oxaliplatin. Pharmazie, 2013; 68(7): 622-627. [DOI: https://doi.org/10.1691/ph.2013.6523]

11. Moin V.M. A simple and specific method for determining the activity of glutathione peroxidase in erythrocytes. Lab. Delo, 1986; 12: 724-727. (In Russian). [Google Scholar]

12. Moiseenok A., Katkovskaya I., Gurinovich V., Denisov A., Pashkevich S., Kul'chitskii V. Absorption and biotransformation of the coenzyme A precursor D-pantethine in rat hippocampus. Neurochemical Journal, 2010; 4(4): 257-264. [Google Scholar]

13. Munoz M., Henderson M., Haber M., Norris M. Role of the MRP1/ABCC1 multidrug transporter protein in cancer. IUBMB Life, 2007; 59(12): 752-757. [DOI: https://doi.org/10.1080/15216540701736285; PMID: 18085475; Google Scholar]

14. Panchuk R.R., Skorokhyd N.R., Chumak V.V., Lehka L.V., Moiseenok A.G., Berger W., Stoika R.S. Selenium-containing compounds and D-panthetine modulate the action of doxorubicin and cisplatin towards drug-resistant tumor cells. Studia Biologica, 2013; 7(3): 33-46. (In Ukrainian). [DOI: https://doi.org/10.30970/sbi.0703.349; Google Scholar]

15. Panchuk R., Skorokhyd N., Chumak V., Lehka L., Omelyanchik S., Gurinovich V., Moiseenok A., Heffeter P., Berger W., Stoika R. Specific antioxidant compounds differentially modulate cytotoxic activity of doxorubicin and cisplatin: in vitro and in vivo study. Croat. Med. J, 2014; 55(3): 206-217.

[DOI: 10.3325/cmj.2014.55.206 PMID: 24891279; PMCID: PMC4049213; Google Scholar]

16. Panchuk R.R., Skorokhyd N.R., Kozak Yu.S., Lehka L.V., Chumak V.V., Omelyanchik S.N., Gurinovich V.A., Moiseenok A.G., Stoika R.S. Antioxidants selenomethionine and D-pantethine decrease negative side effects of doxorubicin in NK/Ly lymphoma-bearing mice. Croat. Med. J, 2016; 57(2): 180-192.

[DOI: 10.3325/cmj.2016.57.180; PMID: 27106359; PMCID: PMC4856192; Google Scholar]

17. Panchuk R.R., Skorokhyd N.R., Kozak Yu.S., Lehka L.V., Moiseenok A.G., Stoika R.S. Tissue-protective activity of selenomethionine and D-panthetine in B16 melanoma-bearing mice under doxorubicin treatment is not connected with their ROS scavenging potential. Croat. Med. J, 2017; 58(2): 171-184.

[DOI: https://doi.org/10.3325/cmj.2017.58.171; Google Scholar]

18. Rice-Evans C.A., Diplock A.T., Symons M.C. Techniques in free radical research. Laboratory Techniques in Biochemistry and Molecular Biology, 1991; 22: 1-278.

[ISBN: 978-0-444-81304-6; ISSN: 0075-7535; Google Scholar]

19. Robyt J.F., Ackerman R.J., Chittenden C.G. Reaction of protein disulfide groups with Ellman's reagent: a case study of the number of sulfhydryl and disulfide groups in Aspergillus oryzae amylase, papain, and lysozyme. Archives of Biochemistry and Biophysics, 1971; 147(1): 262-269.

[DOI: https://doi.org/10.1016/0003-9861(71)90334-1; PMID: 5114933; Google Scholar]

20. Sunde RA, Raines $A M$. Selenium regulation of the selenoprotein and nonselenoprotein transcriptomes in rodents. Advances in Nutrition: An International Review Journal, 2011; 2(2): 138-150.

[DOI: 10.3945/an.110.000240; PMID: 22332043; PMCID: PMC3065762; Google Scholar]

21. Tang J., Zhang L., Gao H., Liu Y., Zhang Q., Ran R., Zhang Z., He Q. Co-delivery of doxorubicin and $\mathrm{P}$-gp inhibitor by a reduction-sensitive liposome to overcome multidrug resistance, enhance anti-tumor efficiency and reduce toxicity. Drug Deliv, 2016; 23(4): 1130-1143.

[DOI: https://doi.org/10.3109/10717544.2014.990651; Google Scholar]

22. Tew K.D. Glutathione-associated enzymes in anticancer drug resistance. Cancer Res, 54, 1994; 4313-4320.

[Google Scholar]

ISSN 1996-4536 (print) • ISSN 2311-0783 (on-line) • Біологічні Студії / Studia Biologica • 2018 • Том 12/№2 • C. 13-24 
23. Townsend D.M., Tew K.D. The role of glutathione-S-transferase in anticancer drug resistance. Oncogene, 2003; 22(47): 7369-7375.

[DOI: https://doi.org/10.1038/sj.onc.1206940; PMID: 14576844; Google Scholar]

24. Versantvoort C.H., Broxterman H.J., Bagrij T., Scheper R.J., Twentyman P.R. Regulation by glutathione of drug transport in multidrug-resistant human lung tumour cell lines overexpressing multidrug resistance-associated protein. Br. J. Cancer, 1995; 72(1): 82-89.

[PMID: 7599070; PMCID: PMC2034163; Google Scholar]

\title{
АНТИОКСИДАНТИ СЕЛЕНОМЕТІОНІН I D-ПАНТЕТИН ВПЛИВАЮТЬ ДИФЕРЕНЦІЙОВАНО НА ДІЮ ДОКСОРУБІЦИНУ НА СИСТЕМУ ГЛУТАТІОНУ КЛІТИН ЛЕЙКОЗУ ЛЮДИНИ З РІЗНИМИ МЕХАНІЗМАМИ РЕЗИСТЕНТНОСТІ ДО XIMІOTЕРAПIÏ IN VITRO
}

\author{
Ю. С. Козак ${ }^{1,2}$, Р. Р. Панчук², Н. Р. Скорохід², \\ Д. С. Семенович 4 , А. Г. МойсєєнокА, Р. С. Стойка ${ }^{1,2,3}$ \\ 1 Львівський національний університет імені Івана Франка \\ вул. Грушевського, 4, Львів 79005, Україна \\ e-mail: juliana.kozzak@gmail.com \\ ${ }^{2}$ Iнститут біології клітини НАН України, вул. Драгоманова, 14/16, Львів 79005, Україна \\ 3 Львівський національний медичний університет імені Данила Галицького \\ вул. Пекарська, 69, Львів 79010, Україна \\ ${ }^{4}$ Iнститут біохімії біологічно активних сполук НАН Білорусі \\ бульвар Ленінського комсомолу, 50, Гродно 230030, Білорусь \\ *Кореспондуючий автор: P. P. Панчук, e-mail: rpanchuk@ukr.net
}

Основними проблемами хіміотерапії раку є швидкий розвиток множинної медикаментозної резистентності (MМР) та виникнення важких побічних ефектів у онкохворих під час лікування [4, 9]. Нещодавно встановлено, що антиоксиданти (селенометіонін - SeMet i D-пантетин - D-Pt) проявляють нефро-, мієло- та гепатопротекторну активність щодо мишей-пухлиноносіїв, лікованих традиційним протипухлинним препаратом доксорубіцином (Dx). Крім того, ці антиоксиданти пригнічують цитотоксичний ефект Dx щодо чутливих до хіміотерапії пухлинних клітин і посилюють ефект препарату щодо певних стійких до хіміотерапії пухлинних клітинних ліній (HL-60/vinc, HL-60/adr), тоді як для інших резистентних клітинних ліній (НСТ-116/Вax(-/-), НСТ-116/p53) такий феномен ми не спостерігали [14-17].

Метою цього дослідження було вивчення потенційних молекулярних механізмів впливу антиоксидантних сполук на функціональний стан системи глутатіону в пухлинних клітинних лініях із різними механізмами стійкості до хіміопрепаратів. У цьому дослідженні було використано клітини лейкемії людини лінії HL-60/wt та її резистентних субліній HL-60/adr (надекспресія MRP-1) i HL-60/vinc (надекспресія P-gp).

Лікування клітин Dx вказало на універсальну (різнобічну) дію цього препарату на рівні глутатіону (GSH, GSSG) у кожній досліджуваній клітинній лінії. Клітини дикого типу (HL-60/wt) характеризувалися 8-разовим зниженням рівня GSH під дією Dx порівняно з контролем, тоді як у клітинах субліній HL-60/vinc та HL-60/adr рівень GSH був підвищений у 2,2 і 8,2 разу (порівняно з контрольними клітинами), відповідно. Використання доксорубіцину також призвело до суттєвої перебудови співвідношення GSSG / GSH у клітинах цих субліній, що призвело до 2-кратного підвищення

ISSN 1996-4536 (print) • ISSN 2311-0783 (on-line) • Біологічні Студії / Studia Biologica • 2018 • Том 12/№2 • C. 13-24 
рівня GSSG у клітинах лінії HL-60/vinc та 2,5-кратного зменшення цього показника в клітинах лінії HL-60/adr. Варто зазначити, що вплив Dx на клітини сублінії HL-60/ vinc призвів до 2,5-кратного збільшення активності глутатіон-S-трансферази. Важливим $\epsilon$ те, що антиоксиданти ефективно знизили цей показник, проте вони не продемонстрували подібного впливу на активність глутатіон-S-трансферази в клітинах сублінії HL-60/adr.

Отже, наші дані демонструють важливу роль антиоксидантів у регуляції функціонального стану системи глутатіону в пухлинних клітинах, що характеризуються різними механізмами стійкості до ліків.

Ключові слова: доксорубіцин, антиоксиданти, глутатіон, глутатіонпероксидаза, глутатіонредуктаза, глутатіон-S-трансфераза

Одержано: 15.08.2018

ISSN 1996-4536 (print) • ISSN 2311-0783 (on-line) • Біологічні Студії / Studia Biologica • 2018 • Том 12/№2 • C. 13-24 